\title{
Lumbar herniated disc treatment with percutaneous hydrodiscectomy
}

\author{
Author: Brazilian Medical Association \\ Participants: Antonio Silvinato, Ricardo S. Simões, Renata F. Buzzini, (DD Wanderley M. Bernardo
}

Final version: March 17, 2017

http://dx.doi.org/10.1590/1806-9282.64.09.778

The Guidelines Project, an initiative of the Brazilian Medical Association, aims to combine information from the medical field in order to standardize producers to assist the reasoning and decision-making of doctors.

The information provided through this project must be assessed and criticized by the physician responsible for the conduct that will be adopted, depending on the conditions and the clinical status of each patient.

\section{SUMMARY}

Lumbar herniated disc are common manifestations of degenerative spine diseases, the main cause of radiated lower back pain. This guideline followed standard of a systematic review with recovery of evidence based on the movement of evidence-based medicine. We used the structured method for formulating the question synthesized by the acronym p.I.C.O., In which the p corresponds to the lumbar herniated disc, i to the treatment intervention with percutaneous hydrodiscectomy, c comparing with other treatment modalities, o the outcome of clinical evolution and complications. From the structured question, we identify the descriptors which constituted the evidence search base in the medline-pubmed databases (636 papers) and therefore, after the eligibility criteria (inclusion and exclusion), eight papers were selected to answer to clinical question. The details of the methodology and the results of this guideline are exposed in annex $i$.

\section{INTRODUCTION}

Lumbar herniated discs are common manifestations of degenerative spine diseases, being the main cause of radiated lower back pain. Conservative treatment with anti-inflammatory and physical therapy provides relief of pain in a significant proportion of patients, and surgery is indicated in nonresponsive patients after at least six weeks of conservative treatment to avoid irreversible structural changes in the nerve roots due to chronic compression'. Microdiscectomy is the surgical intervention of choice for hernias that cause root symptoms, not relieved by conservative treatment ${ }^{2,3}$. Surgery provides $85-95 \%$ of good and excellent results in the short-term postoperative period, however, the recurrence rate of LHD after mi- crodiscectomy has been reported to be approximately $26 \% 4$. The surgical treatment includes a great variety of options: percutaneous, endoscopic, by minimally invasive accesses, open treatments; and segmental arthrodesis may or may not be performed.

Percutaneous hydrodiscectomy was developed as a less invasive alternative for traditional microdiscectomy. The procedure is performed under local anaesthesia with sedation, using an image guided technique and a $3.8 \mathrm{~mm}$ cannulated system to dilate the annular fibres in order to access the disc space. The core material of the disc is mechanically removed using a high speed (non-thermal) salt solution which sprays the tissue. 


\section{OUTCOMES}

\begin{tabular}{|c|c|c|c|c|c|c|c|c|c|}
\hline $\begin{array}{l}\text { Author } \\
\text { Type of Study }\end{array}$ & $\begin{array}{l}\text { Publication } \\
\text { Date }\end{array}$ & $\begin{array}{l}\text { Publication } \\
\text { Status }\end{array}$ & Participants & $\begin{array}{l}\text { Study } \\
\text { Length }\end{array}$ & $\begin{array}{l}\text { Pre and } \\
\text { post-op } \\
\text { VAS MI }\end{array}$ & $\begin{array}{l}\text { Pre and } \\
\text { post-op } \\
\text { lumbar } \\
\text { VAS }\end{array}$ & $\begin{array}{l}\text { Mac- } \\
\text { Nab } \\
\text { Crite- } \\
\text { ria }\end{array}$ & $\begin{array}{l}\text { Complica- } \\
\text { tions }\end{array}$ & Comments \\
\hline $\begin{array}{l}\text { Lo WC, et } \\
\text { al. } 5(B) \\
\text { Case series - } \\
\text { retrospective }\end{array}$ & 2012 & $\begin{array}{l}\text { Preliminary } \\
\text { Report - } \\
\text { pending }\end{array}$ & $\begin{array}{l}97 \text { participants } \\
\text { with } \mathrm{HDL}<6 \mathrm{~mm} \\
\text { and radiculop- } \\
\text { athy confirmed } \\
\text { through imaging. } \\
\text { Extruded and } \\
\text { sequestered discs } \\
\text { were excluded. }\end{array}$ & $\begin{array}{l}6 \\
\text { months }\end{array}$ & $\begin{array}{l}8.2 \pm 1.1 \\
2.8 \pm 1.0 \\
(p<0.05)\end{array}$ & $\begin{array}{l}6.5 \pm 1.7 \\
2.9 \pm 1.2 \\
(p<0.05)\end{array}$ & $\begin{array}{l}88 \% \\
\text { excel- } \\
\text { lent } \\
\text { and } \\
\text { good }\end{array}$ & $\mathrm{n} / \mathrm{r}$ & \\
\hline $\begin{array}{l}\text { Han } \mathrm{H} \text { ), et } \\
\text { al.6(B) } \\
\text { Case series - } \\
\text { retrospective }\end{array}$ & 2009 & $\begin{array}{l}\text { Preliminary } \\
\text { Report } \\
\text { Source - } \\
\text { Kor I Spine }\end{array}$ & $\begin{array}{l}12 \text { participants } \\
\text { with lower back } \\
\text { pain (LBP) and } \\
\text { radiculopathy, and } \\
1 \text { with back pain } \\
\text { only. Extruded } \\
\text { and seques- } \\
\text { tered discs were } \\
\text { excluded. }\end{array}$ & $\begin{array}{l}6 \\
\text { months }\end{array}$ & $\begin{array}{l}8.5 \pm 1.1 \\
2.7 \pm 1.0 \\
(p<0.05)\end{array}$ & $\begin{array}{l}6.2 \pm 1.9 \\
3 \pm 1.4 \\
(p<0.05)\end{array}$ & $\mathrm{n} / \mathrm{a}$ & $\mathrm{n} / \mathrm{r}$ & $\begin{array}{l}\text { "A long follow-up and } \\
\text { additional cases are } \\
\text { needed to confirm } \\
\text { these initial results." }\end{array}$ \\
\hline $\begin{array}{l}\text { Hardenbrook } \\
\text { MA, et al.7(B) } \\
\text { Case series - } \\
\text { retrospective }\end{array}$ & 2013 & $\begin{array}{l}\text { Source - } \\
\text { Internet I } \\
\text { of Spine } \\
\text { Surg }\end{array}$ & $\begin{array}{l}50 \text { participants } \\
\text { with lumbar HNP } \\
\text { secondary radicu- } \\
\text { lopathy confirmed } \\
\text { through MRI in } \\
1-2 \text { levels. Exclud- } \\
\text { ed: free fragment, } \\
\text { central stenosis or } \\
\text { bone holding. }\end{array}$ & $\begin{array}{l}\text { Mean } \\
\text { of } 4.6 \\
\text { months }\end{array}$ & $\mathrm{n} / \mathrm{a}$ & $\mathrm{n} / \mathrm{a}$ & $\mathrm{n} / \mathrm{a}$ & $\mathrm{n} / \mathrm{r}$ & $\begin{array}{l}94 \% \text { of patients pre- } \\
\text { sented improvement } \\
\text { of the symptoms. } \\
6 \% \text { did not experi- } \\
\text { ence improvement } \\
\text { of symptoms. Seven } \\
\text { participants with } \\
\text { initial improvement } \\
\text { after the procedure } \\
\text { had recurrence of } \\
\text { symptoms; of these, } \\
\text { three had recurrence of } \\
\text { LHD at the same level. } \\
\text { Therefore, treatment } \\
\text { failure was } 20 \% \text {. }\end{array}$ \\
\hline $\begin{array}{l}\text { Kowalkows- } \\
\text { ki8(B) } \\
\text { Case series - } \\
\text { retrospective }\end{array}$ & 2013 & $\begin{array}{l}\text { Abstract } \\
\text { Accepted } \\
\text { by ASIPP; } \\
\text { June, } 2013\end{array}$ & $\begin{array}{l}15 \text { participants } \\
\text { with subliga- } \\
\text { mentous lumbar } \\
\text { HNP secondary } \\
\text { radiculopathy in a } \\
\text { single level. }\end{array}$ & $\begin{array}{l}4 \\
\text { months }\end{array}$ & $\begin{array}{l}60 \\
32 \\
(p= \\
0.032)\end{array}$ & $\mathrm{n} / \mathrm{a}$ & $\mathrm{n} / \mathrm{a}$ & $n / r$ & $\begin{array}{l}93 \% \text { of the patients } \\
\text { presented improve- } \\
\text { ment of the symptoms. } \\
\text { Five patients who } \\
\text { reported improvement } \\
\text { of symptoms were } \\
\text { treated with subse- } \\
\text { quent injections of } \\
\text { transforaminal epidural } \\
\text { steroids. }\end{array}$ \\
\hline $\begin{array}{l}\text { Jasper, et al.9(B) } \\
{ }^{\star} \text { Case series - } \\
\text { retrospective }\end{array}$ & 2013 & $\begin{array}{l}\text { Pending - } \\
\text { ePlasty }\end{array}$ & $\begin{array}{l}30 \text { participants } \\
\text { with herniated } \\
\text { disc in levels } \\
1-3 \text { confirmed } \\
\text { through imaging. } \\
\text { Excluded: seques- } \\
\text { trated disc, }>50 \% \\
\text { loss of disc height, } \\
\text { severe DDD } \\
\text { or osteophytes } \\
\text { spinal stenosis } \\
\text { and vertebral } \\
\text { instability. }\end{array}$ & $\begin{array}{l}12 \\
\text { months }\end{array}$ & $\mathrm{n} / \mathrm{a}$ & $\mathrm{n} / \mathrm{a}$ & $\begin{array}{l}73 \% \\
\text { excel- } \\
\text { lent } \\
\text { and } \\
\text { good }\end{array}$ & & $\begin{array}{l}\text { There was a reduction } \\
\text { in the pain score in } 26 \\
\text { of the } 30 \text { participants } \\
(87 \%) \text {. }\end{array}$ \\
\hline $\begin{array}{l}\text { Borshchenko I, } \\
\text { et al.10(B) } \\
\text { Case series - } \\
\text { retrospective }\end{array}$ & 2010 & $\begin{array}{l}\text { Pending } \\
\text { (Abstract - } \\
\text { pilot study) }\end{array}$ & $\begin{array}{l}16 \text { participants } \\
\text { with confirmed } \\
\text { disc bulging (pro- } \\
\text { trusion or small } \\
\text { extrusion) in a } \\
\text { single level. Large } \\
\text { disc extrusion } \\
\text { excluded. }\end{array}$ & $\begin{array}{l}6 \\
\text { months }\end{array}$ & $\mathrm{n} / \mathrm{a}$ & $\mathrm{n} / \mathrm{a}$ & $\begin{array}{l}88 \% \\
\text { excel- } \\
\text { lent } \\
\text { and } \\
\text { good }\end{array}$ & $n / r$ & \\
\hline
\end{tabular}




\begin{tabular}{|c|c|c|c|c|c|c|c|c|c|}
\hline $\begin{array}{l}\text { Author } \\
\text { Type of Study }\end{array}$ & $\begin{array}{l}\text { Publication } \\
\text { Date }\end{array}$ & $\begin{array}{l}\text { Publication } \\
\text { Status }\end{array}$ & Participants & $\begin{array}{l}\text { Study } \\
\text { Length }\end{array}$ & $\begin{array}{l}\text { Pre and } \\
\text { post-op } \\
\text { VAS MI }\end{array}$ & $\begin{array}{l}\text { Pre and } \\
\text { post-op } \\
\text { lumbar } \\
\text { VAS }\end{array}$ & $\begin{array}{l}\text { Mac- } \\
\text { Nab } \\
\text { Crite- } \\
\text { ria }\end{array}$ & $\begin{array}{l}\text { Complica- } \\
\text { tions }\end{array}$ & Comments \\
\hline $\begin{array}{l}\text { Wang W, et } \\
\text { al.11(B) } \\
\text { Case series - } \\
\text { prospective }\end{array}$ & 2010 & $\begin{array}{l}\text { Source: } \\
\text { Chinese J } \\
\text { Pain Med }\end{array}$ & $\begin{array}{l}69 \text { participants } \\
\text { with uncompli- } \\
\text { cated HDL im- } \\
\text { aging by MRI or } \\
\text { CT and that met } \\
\text { the McCulloch } \\
\text { criteria. Exclu- } \\
\text { sion: stenosis of } \\
\text { the mixed type } \\
\text { canal, lumbar } \\
\text { spondylolisthesis } \\
\text { and sequestered } \\
\text { hernia. }\end{array}$ & $\begin{array}{l}9 \\
\text { months }\end{array}$ & $\mathrm{n} / \mathrm{a}$ & $\mathrm{n} / \mathrm{a}$ & $\begin{array}{l}98.6 \% \\
\text { excel- } \\
\text { lent } \\
\text { and } \\
\text { good }\end{array}$ & $\begin{array}{l}\text { One case } \\
\text { of infec- } \\
\text { tion in the } \\
\text { disc space }\end{array}$ & \\
\hline $\begin{array}{l}\text { Cristante, et } \\
\text { al.12(B) } \\
{ }^{*} \text { RCT }\end{array}$ & 2013 & Pending & $\begin{array}{l}40 \text { pts with MRI } \\
\text { evidence of small } \\
\text { herniated disc or } \\
\text { protrusion on a } \\
\text { single level were } \\
\text { randomized for } \\
\text { open lumbar } \\
\text { microdiscectomy } \\
\text { or percutaneous } \\
\text { hydrodiscectomy. }\end{array}$ & $\begin{array}{l}12 \\
\text { months }\end{array}$ & $\begin{array}{l}\text { There } \\
\text { was a } \\
\text { statisti- } \\
\text { cally sig- } \\
\text { nificant } \\
\text { improve- } \\
\text { ment }\end{array}$ & $\begin{array}{l}\text { No sta- } \\
\text { tistically } \\
\text { significant } \\
\text { improve- } \\
\text { ment }\end{array}$ & $\mathrm{n} / \mathrm{a}$ & $\begin{array}{l}\text { One } \\
\text { with PO } \\
\text { infection. } \\
\text { One death } \\
\text { related to } \\
\text { underlying } \\
\text { disease } \\
\text { (HIV) }\end{array}$ & $\begin{array}{l}20 \% \text { of patients had } \\
\text { subsequent interven- } \\
\text { tion. }\end{array}$ \\
\hline 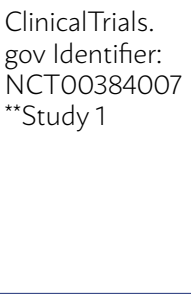 & $\begin{array}{l}\text { Closed } \\
\text { Last Up- } \\
\text { dated June } \\
\text { 4, } 2009 \\
\text { ClinicalTri- } \\
\text { als.gov ac- } \\
\text { cessed on } \\
\text { 18/11/2015 }\end{array}$ & $\begin{array}{l}\text { No esti- } \\
\text { mated date } \\
\text { for publica- } \\
\text { tion }\end{array}$ & & & & & & & \\
\hline $\begin{array}{l}\text { ClinicalTrials. } \\
\text { gov Identifier: } \\
\text { NCTO2414698 } \\
{ }^{* \star *} \text { Study } 2\end{array}$ & $\begin{array}{l}\text { Recruiting } \\
\text { patients. } \\
\text { ClinicalTri- } \\
\text { als.gov ac- } \\
\text { cessed on } \\
\text { 18/11/2015 }\end{array}$ & & & & & & & & \\
\hline
\end{tabular}

$\mathrm{MI}=$ lower member; $\mathrm{PO}=$ postoperative; $\mathrm{LHD}=$ lumbar herniated disc; $\mathrm{LBP}=$ lower back pain, $\mathrm{n} / \mathrm{a}=$ not available; $\mathrm{n} / \mathrm{r}$ none reported; $\mathrm{HNP}=$ herniated nucleus pulposus; $\mathrm{MRI}=$ magnetic resonance imaging; DDD = disc degenerative disease; McCulloch Criteria = no improvement in symptoms after $\geq 3$ months of conservative treatment; RCT = randomized controlled trial. * Data recovered at http://www.washawaybackpain.com/uploads/studies/Clinical\%20Evaluation.docx (complete text not available).

\section{CLINICALTRIALS.GOV PROCESSED THIS RECORD ON NOVEMBER 18, 2015}

\section{** Study 1:}

Title: A Randomized Trial Comparing Spinejet ${ }^{\circledR}$ Hydrodiscectomy to Open Lumbar Microdiscectomy for Treatment of Lumbar Radiculopathy Due to Disc Herniation

Recruitment: Completed

Study First Received: October 2, 2006

Last Updated: June 4, 2009

Study Results: No Results Available

Conditions: Disc Herniation With Radiculopathy

Interventions: Procedure: Hydrodiscectomy with Spinejet

URL: https://ClinicalTrials.gov/show/NCT00384007

\section{*** Study 2:}

Title: Percutaneous HydroDiscectomy Compared to TESI for Radiculopathy

Recruitment: Recruiting

Study Results: No Results Available

Conditions: Lumbar Herniated Disc

Interventions: Procedure: Percutaneous Hydrodiscectomy|Drug: TESI

URL: https://ClinicalTrials.gov/show/NCT02414 


\section{DISCUSSION}

Three characteristics are essential for a good systematic review of the literature: to gather all available evidence until the most recent moment; assess the quality of the studies individually and finally, summarize the results of the studies found. In this review on the use of percutaneous hydrodiscectomy in the treatment of lumbar herniated disc, we did not find any study in the scientific information databases consulted (Medline via PubMed, Central and Lilacs via BVS, Embase and Cinahl via Ebsco). With handsearching accessing the grey literature, of the eight included studies, only three case series present full text, impairing the assessment of studies quality. Therefore, caution is advised in interpreting the results, as they may present distortions of reality. In a search in the Clinical Trials database (https://clinical- trials.gov/ - accessed on 11/18/2015), which registers protocols of studies to be conducted, we found a randomized controlled trial completed (NCTO0384007 "Last Update June 4, 2009 “- no results available) and one in progress (NCTO2414698).

\section{RECOMMENDATION:}

The available evidence related to percutaneous hydrodiscectomy in the treatment of lumbar herniated disc is very weak, and its clinical use, generalized and systemic, is not recommended at this time. Its use should be restricted to the clinical research environment, so that data on efficacy and safety are produced consistently and strongly.

(Oxford 2009 ${ }^{13}$ - Level of evidence 4 and Degree of Recommendation C; Grade ${ }^{14}$ 1D)

\section{RESUMO}

Hérnias discais lombares são manifestações comuns das doenças degenerativas da coluna, sendo a principal causa de dor lombar irradiada. Esta diretriz seguiu padrão de uma revisão sistemática com recuperação de evidências com base no movimento da Medicina Baseada em Evidências. Utilizamos a forma estruturada de formular a pergunta sintetizada pelo acrônimo P.I.C.O., em que o P corresponde à Hérnia de disco lombar, I à intervenção Tratamento com hidrodiscectomia percutânea, C comparando com Outras modalidades de tratamento, $O$ de desfecho de Evolução clínica e complicações. A partir da pergunta estruturada, identificamos os descritores que constituíram a base da busca da evidência nas bases de dados Medline-PubMed (636 trabalhos) e, assim, após os critérios de elegibilidade (inclusão e exclusão), oito trabalhos foram selecionados para responder à dúvida clínica. Os detalhes da metodologia e dos resultados desta diretriz estão expostos no Anexo I.

\section{ANNEX I}

\section{Structured question}

The clinical question is structured through the components of P.I.C.O.

\section{TABLE 1 - PICO COMPONENTS}

\begin{tabular}{l|l}
\hline $\mathbf{P}$ & Lumbar herniated disc in one or more levels \\
\hline $\mathbf{I}$ & Treatment with percutaneous hydrodiscectomy \\
\hline $\mathbf{C}$ & Other treatment modalities \\
\hline $\mathbf{O}$ & Clinical evolution and complications \\
\hline (P (Patient); I (Intervention); C (Comparison); O (Outcome).
\end{tabular}

\section{Evidence search strategy}

The bases of scientific information consulted were Medline via PubMed, Central and Lilacs via BVS, Cochrane Library and Embase. Handsearch from references of selected papers was also performed.

\section{PubMed-Medline}

TABLE 2 - SEARCH STRATEGY USED IN THE SCIENTIFIC INFORMATION DATABASES

Without methodological filter

Search 1: (lumbar herniated nucleus pulposus OR disc herniation OR disc hernia OR intervertebral disk displacement) AND (percutaneous lumbar discectomy OR percutaneous mechanical disc decompression OR percutaneous discectomy OR diskectomy percutaneous OR hydro discectomy OR hydro surgical decompression OR spinejet OR percutaneous microdiscectomy) - 624 studies RECOVERED.

Search 2: (percutaneous hydrodiscectomy OR hydrodiscectomy OR spinejet) - One study RECOVERED.

Initially selected by the title, sequentially by the abstract, and finally by its full text, the latter being subjected to critical evaluation and extraction of the results related to the outcomes.

TABLE 3 - NUMBER OF PAPERS RECOVERED WITH THE SEARCH STRATEGY USED FOR THE SCIENTIFIC INFORMATION DATABASES

\begin{tabular}{l|l|l} 
Information base & Number of papers & $\begin{array}{l}\text { Number of selected } \\
\text { papers }\end{array}$ \\
\hline Primary & 624 & 0 \\
\hline Grey literature & 12 & 8 \\
\hline
\end{tabular}

PAPERS RECOVERED (until 11/29/2015) 


\section{Inclusion criteria for the papers recovered}

The selection of the studies, review of the titles and abstracts obtained with the search strategy in the consulted information bases was conducted by two researchers with skills in the preparing systematized reviews, independently and blindly, strictly following the inclusion and exclusion criteria established, thus selecting the papers with potential relevance.

\section{According to the study designs}

Narrative reviews, case reports, case series, papers presenting preliminary results were, at first, excluded from selection. Systematic reviews and meta-analyses were used with the principle of retrieving references that might have been lost at first in the initial search strategy. We included systematic reviews (SRs) of randomized controlled trials (RCTs) and randomized controlled trials not included in the SRs. The controlled clinical trials were evaluated according to the Jadad score ${ }^{13}$ and the Grade score $^{14}$.

\section{Papers recovery}

The papers recovered were evaluated by title, abstract and full text (when available), allowing the initial selection of studies to be critically evaluated. After the critical evaluation, we obtained the final selection of the studies (8), with or without full text, that provided the data for the overall synthesis. The main reasons for exclusion were: did not respond to PICO, cadaver study and case report.

\section{REFERENCES}

1. Schoenfeld AJ, Weiner BK. Treatment of lumbar disc herniation: Evidence-based practice. Int I Gen Med 2010 21;3:209-14. PMID: 20689695.

2. Kostuik JP, Harrington I, Alexander D, Rand W, Evans D. Cauda equina syndrome and lumbar disc herniation. J Bone Joint Surg Am 1986; 68:38691. PMID: 2936744.

3. Awad IN, Moskovich R. Lumbar disc herniations: surgical versus nonsurgical treatment. Clin Orthop Relat Res 2006; 443:183-97. PMID: 16462442.

4. Carragee EJ, Han MY, Suen PW, Kim D. Clinical outcomes after lumbar discectomy for sciatica: the effects of fragment type and anular competence. | Bone Joint Surg Am 2003; 85-A(1):102-8. PMID: 12533579.

5. Lo WC. Minimally Invasive Percutaneous Hydrodiscectomy: Preliminary Report. Presented at Taiwan Society of Minimally Invasive Spine Surgery, October 13, 2012.

6. Han HJ, Kim WK, Park CK, et al. Minimally Invasive Percutaneous Hydrodiscectomy: Preliminary Report. Kor J Spine; 2009;6(3):187-191

7. Hardenbrook MA, Gannon DP, Younan E, et al. Clinical Outcomes of Patients Treated with Percutaneous Hydrodicectomy for Radiculopathy Seconary to Lumbar Herniated Nucleus Pulposus. Internet | of Spine Surg; 2013:ISSN: 1937-8270.

8. Kowalkowski T. Preliminary Results of Patients Treated with Percutane-

\section{Language}

Studies in Portuguese, English and Spanish languages were included.

\section{According to the publication}

Only papers for which the complete text was available were considered for critical evaluation.

\section{Critical evaluation methods}

When, after applying the inclusion and exclusion criteria, the selected evidence was defined as randomized a controlled trial (RCT), it was submitted to an appropriate critical evaluation checklist.

\section{Results exposure}

For results with available evidence, population, intervention, outcomes, presence or absence of benefit and/or damage and possible comments will be specifically defined, whenever possible.

\section{Recommendations}

The recommendations will be prepared by the authors of the review, with the initial characteristic of evidence synthesis, being submitted to validation by all the authors participating in the preparation of the guideline.

The degree of recommendation to be used comes directly from the available strength of the included studies $^{15}$ and the use of the Grade system ${ }^{14}$.

\section{Conflict of Interest}

No conflict of interest was declares by the participants in the preparation of this guideline.

ous Hydrodiscectomy for Radiculopathy Seconary to Herniated Nucleus Pulpsus. Abstract Submitted to ASIPP; June, 2013.

9. Jasper G. Minimally Invasive Percutaneous Hydrodiscectomy: Preliminary Report on 30 Consecutive Cases. ePlasty 2013 publication pending.

10. Borshchenko I, Baskov A, Sergey M. Percutaneous Lumbar Hydrodiscectomy: pilot experience. 2010; Publication pending.

11. Wang $W$, Xiantong $Y$, jianjun $C$, et al. Treatment of Lumbar Disc Herniation through Percutaneous Hydrodiscectomy. Chinese I Pain Med; 2010;16(2):71-75.

12. Cristante AF, Dias da Rocha I, Marcon RM, et al. Randodmized study comparing lumbar microdiscectomy with Spinejet in the treatment of lumbar disc protrusions. Publication pending, 2013.

13. Jadad AR, Moore RA, Carroll D, Jenkinson C, Reynolds DJ, Gavaghan DJ, et al. Assessing the quality of reports of randomized clinical trials: is blinding necessary? Control Clin Trials 1996; 17:1-12.

14. Goldet G, Howick J. Understanding GRADE: an introduction. J Evid Based Med 2013; 6:50-4.

15. Levels of Evidence and Grades of Recommendations - Oxford Centre for Evidence Based Medicine. Disponível em URL: http://www.cebm.net/oxford-centre-evidence-based-medicine-levels-evidence-march-2009/ 